\title{
Letter
}

||||||||||||||||||||||||||||||||||||||||||||

\section{Uranium $\left(\mathrm{UO}_{2}{ }^{2+}\right)$ Retention Property of Degraded $\boldsymbol{n}$-dodecane by Acidic Radiolysis in the Purex Process ${ }^{\dagger}$}

\author{
Hidematsu IKEDA $^{\dagger \dagger}$, Manabu ToKESHI and Takehiko KITAMORI* \\ Kanagawa Academy of Science and Technology (KAST), \\ Special Research Laboratory for Optical Science, Micro Chemistry Group \\ KSP East 307, 3-2-1, Sakado, Takatsu-ku, Kanagawa Pref. 213-0012, Japan \\ *The University of Tokyo, School of Engineering \\ 7-3-1 Hongo, Bunkyo-ku, Tokyo 113-8656, Japan
}

Received October 14, 2004

\begin{abstract}
Radiation effects on the uranium retention property of degraded $n$-dodecane by acidic radiolysis in the Purex process were studied. The absorbed dose of n-dodecane varied from 24.04 to $2403.69 \mathrm{kGy}$ (5 to 500 $\left.\mathrm{Wh} / \mathrm{dm}^{3}\right)$. When the absorbed dose exceeded $48.07 \mathrm{kGy}\left(10 \mathrm{Wh} / \mathrm{dm}^{3}\right)$, the uranium $\left(\mathrm{UO}_{2}{ }^{2+}\right)$ was retained in degraded n-dodecane even without TBP as extractant. An empirical correlation of the uranium retention was also derived. This correlation is a very effective one because it can especially be used for the prediction of the amount of retained uranium in the degraded n-dodecane. Data obtained through this work should be useful for the process design under solvent degradation conditions in nuclear fuel processing facilities especially in reused solvent.
\end{abstract}

Key Words : uranium retention, degraded dodecane, acidic radiolysis, wet method, Purex process

\section{Introduction}

$n$-dodecane is commonly used not only as a diluent of tri- $n$-butyl phosphate (TBP) but also as a cleaner of degraded TBP. Fresh dodecane is used to recover organic fragments from the product streams in the TBP scrubbers of the Purex system. The raffinate from the high activity column (HA column) in the Purex system is also scrubbed with fresh $n$-dodecane.

†ピューレックスプロセスにおける酸共存放射線劣 化ドデカンへのウラン担持。池田秀松, 渡慶次 学, 北森武彦*：財団法人神奈川科学技術アカデミー (KAST) 光科学重点研究室 マイクロ化学グルー プ，213-0012，神奈川県川崎市高津区坂戸 3-2-1, KSP東棟307, *東京大学大学院工学系研究科, 1138656，東京都文京区本郷 7-3-1。
Major actinides (uranium and plutonium) are separated from the fission products (FP) by using TBP in the HA column. A $30 \mathrm{vol} \% \mathrm{TBP} / n$ dodecane mixture is used as the extractant for the major actinides in all steps of the Purex system, while a $80 \mathrm{vol} \% \mathrm{TBP} / n$-dodecane mixture is used as the washing solution to recycle the solvent for re-use in the degraded solvent scrubber. And these solvent mixtures undergo degradation when they are irradiated and/or come into contact with nitric acid. The effects of radiation exposure on decomposition of the liquid system in the Purex process have been

\footnotetext{
${ }^{\dagger \dagger}$ Corresponding author

Tel. +81-44-819-2037\&+81-44-850-1125

Fax. +81-44-819-2092

E-mail : ikeda@pop12.odn.ne.jp
} 
investigated since the early $1950 \mathrm{~s}^{11}$, and basic data for application of TBP were reviewed by Schulz and Navratil ${ }^{2}$. Some reports on degradation of Purex liquids by the wet method have been published; but they were devoted mainly to studies of TBP degradation products ${ }^{1-6)}$. At the radiation energy level present in the actual Purex process, both decrease of the separation efficiency and of the solvent recovery rate are more serious problems than the loss of recyclable nuclear materials ${ }^{7}$. The loss of the uranium to the degraded solvent is the important problem still. And the relations between the radiolysis of $n$-dodecane and the uranium retention are not reported at present. The uranium retention of radiolytically degraded $n$-dodecane has been discussed in this papers. This work is the first report in the uranium retention in degraded $n$-dodecane by acidic radiolysis in the Purex process.

On the other hand, the major actinide retention of chemically degraded diluents has been discussed in several papers ${ }^{3 /, 8), 9}$. Ishihara and Ohwada $^{3)}$ found the distribution ratio of uranium decreased under the conditions for kerosene degradation of nitric acid concentration above $5 \mathrm{M}$ and temperatures of $70{ }^{\circ} \mathrm{C}$ or $110{ }^{\circ} \mathrm{C}$. Uranium retention tests based on the chemically degraded solvent and the actual irradiated solvent were done by Tallent and Mailen ${ }^{8}$. From the chemical degradation results, it was found that the uranium concentration in washed solvent decreased from 24.5 to $<0.056 \%$ as the $\left(\mathrm{N}_{2} \mathrm{H}_{5}\right)_{2} \mathrm{C}_{2} \mathrm{O}_{4}$ concentration was increased from 0.041 to $0.246 \mathrm{M}$. They also observed the loss of uranium in stripped solvent was $0.103 \%$ by the actual irradiation. The plutonium retention of chemically degraded NPH has been reported by Tallent et al. ${ }^{9}$. They found that the $\mathrm{NPH}$ in contact with $8.2 \mathrm{M} \mathrm{HNO}_{3}$ was $21.3 \%$ de- graded after $6.75 \mathrm{~h}$ at $108{ }^{\circ} \mathrm{C}$, and the degradation rate of NPH without TBP remained approximately constant with time. When the NPH was $25 \%$ degraded, they also found plutonium $\left(\mathrm{Pu}^{4+}\right)$ was retained in it even when TBP was not present. In another study, from radiolytic experiments at Windscale, Lane ${ }^{10)}$ found that secondary products of thermal and radiolytic degradation of hydrocarbons were responsible for the metal retention. Cleanup methods for the pretreatment process of badly degraded solvents were also proposed in this report.

Although these previous studies provided many useful data for analysis of metal retention behavior in the Purex liquid system, basic data on the uranium retention of radiolytically degraded solution used in facilities is still poorly understood. And the retained behavior of major actinide in the radiolytically degraded $n$-dodecane was not reported still now. In the present work, the radiation effects on the uranium retention property of degraded $n$-dodecane by acidic radiolysis (wet method) in the Purex process were studied. The relations between the radiolysis of $n$-dodecane and the uranium retention were reported here now and first. This report is especially effective in predicting the loss of the uranium to the radiolytically degraded $n$-dodecane. The loss of recyclable nuclear materials is increased when the solvent absorbs high radiation doses (e.g., when short-cooled, high-burnup fuel is processed), and large amounts of degradation products are formed or allowed to build up through incomplete cleanup of recycled solvent. Then the amount of uranium in the degraded $n$-dodecane can be predicted with this report and the empirical correlations. Data obtained through this work should be useful for the process design 
Table 1 Experimental conditions of $\mathrm{UO}_{2}^{2+}$ retention test in degraded $n$-dodecane

\begin{tabular}{|c|c|c|l|}
\hline & Reagent & $\mathrm{A} / 0$ & \multicolumn{1}{c|}{ Conditions } \\
\hline Retention & $0.1 \mathrm{M} \mathrm{UO}_{2}{ }^{2+}$ & 1 & $\begin{array}{l}25^{\circ} \mathrm{C} \\
\text { Shaker: } 250 \mathrm{spm}, 30 \mathrm{~mm}, 10 \mathrm{~min}\end{array}$ \\
\hline Washing & Pure water & 1 & $\begin{array}{l}25^{\circ} \mathrm{C} \\
\text { Shaker }: 250 \mathrm{spm}, 30 \mathrm{~mm}, 10 \mathrm{~min}\end{array}$ \\
\hline
\end{tabular}

under solvent degradation conditions in nuclear fuel processing facilities.

\section{Experimental}

$2 \cdot 1$ Materials and irradiation conditions

All chemicals were reagent grade or better. The aqueous U(VI) samples were prepared by diluting $0.1 \mathrm{M}$ stock solution of uranium nitrate in $3 \mathrm{M} \mathrm{HNO}_{3}$. $n$-dodecane from Tokyo Kasei Kogyo (Tokyo Chemical Industry) Co. Ltd. was used without further purification. Its purity was $99.26 \%$, while $n$-undecane and $n$-tridecane had impurity amounts of $0.54 \%$ and $0.20 \%$ respectively ${ }^{11}$. The acidic radiolysis of $n$-dodecane with $3 \mathrm{M} \mathrm{HNO}_{3}$ was studied. Samples for irradiation were put in lidded flasks (each one liter volume), and irradiated with $\mathrm{a}^{60} \mathrm{Co} \gamma$ source facility at the University of Tokyo. Samples were irradiated while being mixed with a magnetic stirrer in the presence of air at $25{ }^{\circ} \mathrm{C}$. The absorbed dose of $n$-dodecane varied from 24.04 to $2403.69 \mathrm{kGy}\left(5\right.$ to $\left.500 \mathrm{Wh} / \mathrm{dm}^{3}\right)$. The dose range was based on the dose in one pass through a reference HA column in the Purex process $^{11}$. This range covered a serious damage of $48.08 \mathrm{kGy}\left(10 \mathrm{Wh} / \mathrm{dm}^{3}\right)$ to $1153.92 \mathrm{kGy}$ $\left(240 \mathrm{Wh} / \mathrm{dm}^{3}\right)$ at which TBP began to form polymer ${ }^{7)}$.

\section{$2 \cdot 2$ Measurement}

The experimental procedure and conditions are shown in Fig.1 and Table 1. Each sample was measured three times under the same con-

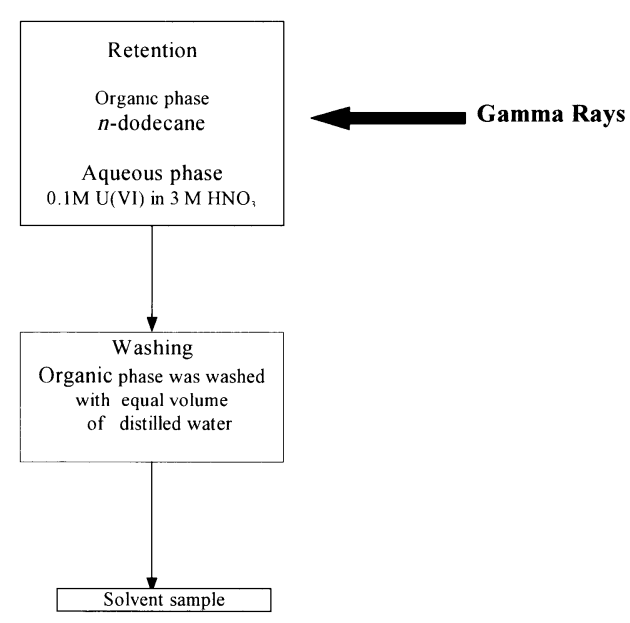

Fig. 1 Outline of experimental procedure.

ditions, and the average value was adopted. At the end of each procedure, the organic and aqueous phases were separated by a mechanical shaker, and the U(VI) concentrations in each phase measured with a Hitachi Model U3010 spectrophotometer.

\section{Results and Discussion}

Aqueous and organic phase spectra showing uranium retention in degraded $n$-dodecane at the dose of $1442.21 \mathrm{kGy}\left(300 \mathrm{Wh} / \mathrm{dm}^{3}\right)$ are shown in Fig.2. These spectra exhibit absorption peaks of $\mathrm{U}(\mathrm{VI})$.

Representative results of the uranium retention test applied to the degraded $n$-dodecane by acidic radiolysis ${ }^{12)}$ 13) are shown in Fig.3. When the absorbed dose exceeded $48.07 \mathrm{kGy}$ $\left(10 \mathrm{Wh} / \mathrm{dm}^{3}\right)$, the uranium $\left(\mathrm{UO}_{2}{ }^{2+}\right)$ was re- 

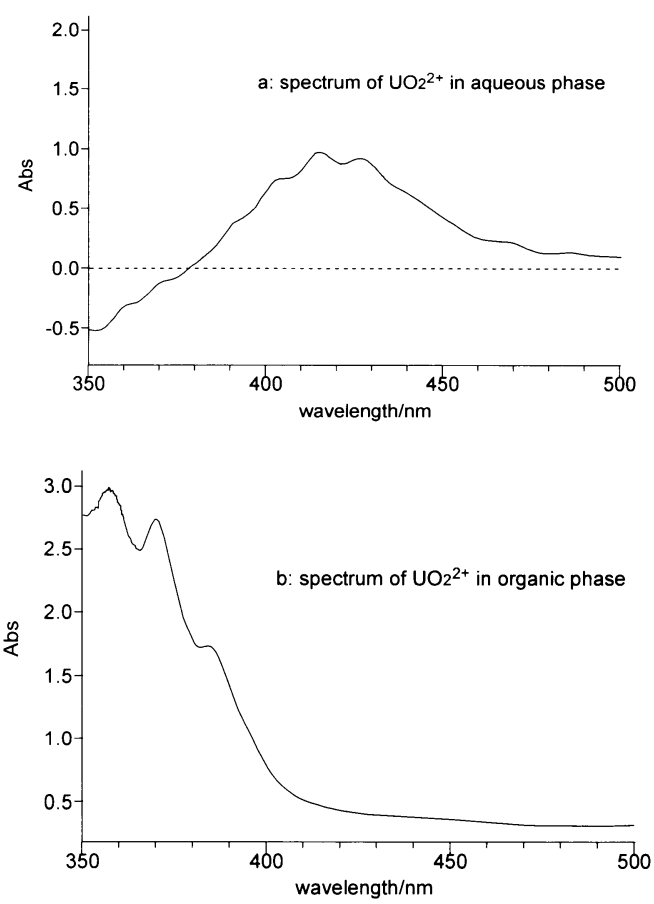

Fig. $2 \mathrm{UO}_{2}{ }^{2+}$ retention in degraded $n$-dodecane at the dose of $1442.21 \mathrm{kGy}\left(300 \mathrm{Wh} / \mathrm{dm}^{3}\right)$. (Aqueous (a) and Organic (b))

tained in degraded $n$-dodecane even when TBP was not present. Figure 3 shows that the uranium retention slightly increase with the absorbed dose. The retention of uranium in degraded $n$-dodecane for both $240.37 \mathrm{kGy}(50 \mathrm{Wh}$ $\left./ \mathrm{dm}^{3}\right)$ and $2403.69 \mathrm{kGy}\left(500 \mathrm{Wh} / \mathrm{dm}^{3}\right)$ were $0.1909 \mathrm{~g} / \mathrm{dm}^{3}$ and $1.3957 \mathrm{~g} / \mathrm{dm}^{3}$, respectively. The dodecane was about $1.8 \%$ degraded absorption of $240.37 \mathrm{kGy}\left(50 \mathrm{Wh} / \mathrm{dm}^{3}\right)$. This degradation was determined by a GC-MS ${ }^{11}$.

Although $1.8 \%$ degradation with the absorbed dose of $240.37 \mathrm{kGy}\left(50 \mathrm{Wh} / \mathrm{dm}^{3}\right)$ was smaller than the $25 \%$ with the chemical degradation ${ }^{9}$, uranium $\left(\mathrm{UO}_{2}{ }^{2+}\right)$ was retained in degraded $n$-dodecane even without TBP as extractant.

Generally, a distinction has been made between chemical and radiolytic degradation of

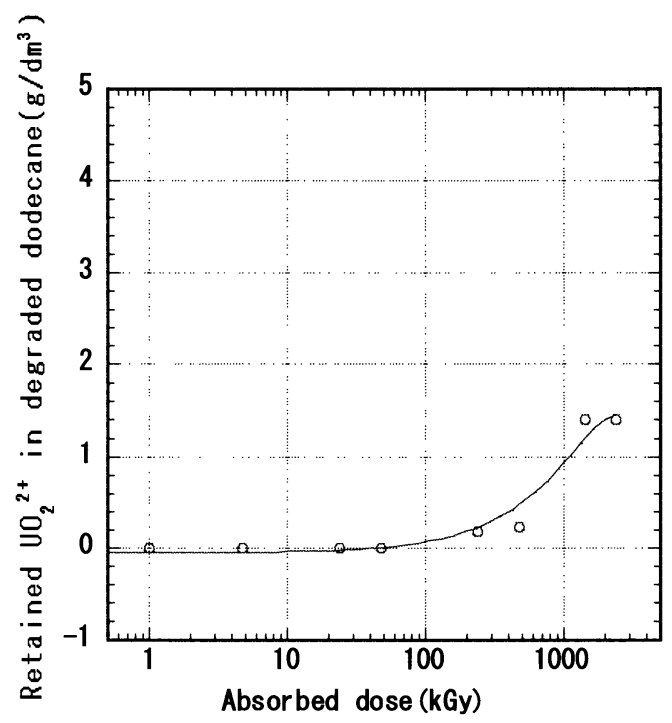

Fig. 3 Radiation effects on $\mathrm{UO}_{2}{ }^{2+}$ retention in degraded $n$-dodecane by acidic radiolysis.

TBP- $n$-dodecane solvents; however, since both radiolytic and chemical degradation proceeds through free radical mechanisms, the products obtained may be similar ${ }^{11}$. A large variety of additional $n$-alkane degradation products were observed through both degradation processes, and the basic chemical species were almost the same ${ }^{5), 9,11)}$, but the yields of the long-chain organic acids such as aliphatic acids might have been different. Chromatograms of degraded $n$ dodecane revealed the formation of dimer ${ }^{11}$, but no formation of polymer was observed in this work. The chemical species from light alkanes to the dimer were formed by the radiolysis of $n$-dodecane; thus, the physical property changes were observed. From the experimental results ${ }^{11)}$ it can be seen that the changes in the physical property rapidly increase at absorption higher than $240.37 \mathrm{kGy}\left(50 \mathrm{Wh} / \mathrm{dm}^{3}\right)$. The influence of the exposure dose is more effective in the viscosity change than the density. It is assumed that the tendency in physical 
Table 2 Empirical correlations of $\mathrm{UO}_{2}{ }^{2+}$ retention test in degraded $n$-dodecane as obtained from Fig.3

\begin{tabular}{|c|c|c|}
\hline $\begin{array}{c}\mathrm{URD}_{\mathrm{RD}}: \mathrm{UO}_{2}{ }^{2+} \text { retention }\left(\mathrm{g} / \mathrm{dm}^{3}\right) \\
\mathrm{D}: \text { Absorbed dose }(\mathrm{kGy})\end{array}$ & \multicolumn{2}{|c|}{$\begin{array}{c}\mathrm{U}_{\mathrm{RD}}: \mathrm{UO}_{2}{ }^{2+} \text { retention }\left(\mathrm{g} / \mathrm{dm}^{3}\right) \\
\text { D: Absorbed dose }(\mathrm{kGy})\end{array}$} \\
\hline \multirow{2}{*}{$\mathrm{D}<48 \mathrm{kGy}$} & \multicolumn{2}{|c|}{$\mathrm{D} \geqq 48 \mathrm{kGy}$} \\
\hline & \multicolumn{2}{|c|}{$U_{R D}=a 0+a 1 \cdot D+a 2 \cdot D^{2}$} \\
\hline \multirow{4}{*}{$\mathrm{U}_{\mathrm{RD}}=0$} & $\mathrm{a} 0$ & -0.052965 \\
\hline & $\mathrm{a} 1$ & 0.0012519 \\
\hline & $\mathrm{a} 2$ & $-2.604 \mathrm{e}-07$ \\
\hline & $R$ & 0.98001 \\
\hline
\end{tabular}

property changes increase because this experiment was done for acidic radiolysis. The degradation yield of the acidic radiolysis will be larger than that of the radiolysis only, since for acidic radiolysis the chemical and radiolytic degradation by nitric acid took place at the same time. The magnitude of physical property changes was small but could not be ignored, because the long-chain organic acids formed by the degradation of diluent such as $n$ dodecane affect the retention of heavy met$\mathrm{als}^{9), 10}$. These acids are suspected to be the source of the actinide retention and/or the phase separation problem, since contact with the actinide ions causes the organic acids such as lauryl acid to form complexes.

An empirical correlation of the uranium retention (Table 2) was obtained from Fig.3, where $\mathrm{R}$ is the correlation coefficient, and D is the absorbed dose in $\mathrm{kGy}$ of $n$-dodecane. This correlation based on the experiment can be applied for the process design under the solvent degradation conditions in nuclear fuel processing facilities, especially in reused solvent. The empirical correlation is a very effective one because it can especially be used for the prediction of the amount of retained uranium in the degraded $n$-dodecane.

\section{Concluding Remarks}

The uranium $\left(\mathrm{UO}_{2}{ }^{2+}\right)$ retention property of radiolytically degraded $n$-dodecane was evaluated and the following three conclusions were obtained. From them an empirical correlation for the prediction of the amount of retained uranium in the degraded $n$-dodecane was derived.

(1)When the absorbed dose exceeded 48.07 $\mathrm{kGy}\left(10 \mathrm{Wh} / \mathrm{dm}^{3}\right)$, the uranium $\left(\mathrm{UO}_{2}{ }^{2+}\right)$ was retained in degraded $n$-dodecane even without TBP as extractant.

(2)The retention of uranium for $240.37 \mathrm{kGy}$ $\left(50 \mathrm{Wh} / \mathrm{dm}^{3}\right)$ and $2403.69 \mathrm{kGy}(500 \mathrm{Wh} /$ $\mathrm{dm}^{3}$ ) was $0.1909 \mathrm{~g} / \mathrm{dm}^{3}$ and $1.3957 \mathrm{~g} / \mathrm{dm}^{3}$, respectively.

(3) $n$-dodecane was about $1.8 \%$ degraded by absorption $240.37 \mathrm{kGy}\left(50 \mathrm{Wh} / \mathrm{dm}^{3}\right)$.

\section{References}

1) Benedict, M., Pigford, T. H. and Levi, H. W., Nuclear Chemical Engineering (2nd ed.), Chap.10, McGrow-Hill, New York (1981)

2) Schitz, W. W. and Navratil, J. D., Science and Technology of Tributyl Phosphate, Vol. I(1st ed.), CRC Press, FL (1984)

3) Ishihara, T. and Ohwada, K., The efect of hydrogen bond formation between tri- $n$-butyl phosphate and carboxylic acid on uranium distribu- 
tion, J. Nucl. Sci. Technol ., 3 (2), 67-71 (1965)

4) Brodda, B. G. and Heinen, D., Solvent performance in THTR nuclear fuel reprocessing. Part II : On the formation of dibutyl phosphoric acid by radiolytic and hydrolytic degradation of the TBP -n-paraffin extractant, Nucl. Technol ., 34, 428-437 (1977)

5) Kulikov, I. A. et al., Gamma-radiolysis of TBP and DBPA in the presence of $\mathrm{HNO}_{3}$, Radiokimiya, 27 (1), 65-70(1985)

6) Adamov, B. M. et al., Radiolysis of an extraction system based on solution of tri- $n$-butylphosphate in hydrocarbon diluents, Radiokhimiya, 31 (1), 822 $-829(1987)$

7) Ishihara, T. and Tsujino, T. and Yamamoto, Y., Radiation damage to TBP/kerosene solventEffect on behaviors of fission products and nitric acid, Nihon-Genshiryoku-Gakkaishi (J. At. Energy Soc. Jpn. ), 2(11), 1-12(1960) [in Japanese]

8) Tallent, O. K. and Mailen, J. C., An alternative solvent cleanup method using hydrazine oxalate wash reagent, Nucl. Technol., 59, 51-62(1982)

9) Tallent, O. K., Mailen, J. C. and Dodson, K. E., Purex diluent chemical degradation, Nucl.Technol ., 74, 417-425(1985)

10) Lale, E. S., Performance and degradation of diluents for TBP and the cleanup of degraded solvents, Nucl.Sci. Eng., 17, 620-625(1963)

11) Ikeda, H. and Suzuki, A., Radiolysis of $n$-dodecane and its physical property change-based on the dose in one pass through a reference HA columns, J. Nucl. Sci. Technol ., 36 (10), 697-704 (1998)

12) Ikeda, H. and Suzuki, A., Empirical correlations for radiolytic degradation of $n$-dodecane-density, viscosity and phase separation time, J.Nucl.Sci. Tecnol ., 38 (12), 1138-1140 (2001)

13) Ikeda, H., Safety design of purex liquids system - the flash point and the fire point, J.Nucl.Sci.Tecnol ., 41 (4), 534-536(2004) 